石油技術協会誌 第 69 巻 第 1 号 (平成16年 1月)

JOURNAL OF THE JAPANESE ASSOCIATION FOR PETROLEUM TECHNOLOGY

VOL. 69, NO. 1 (Jan., 2004)

$\overline{\text { 講 演 }}$

米国の対中東政策と日本

一対中東「ブッシュ・ドクトリン」の日本へのインプリケーション一*

松 永 泰 行**

(Received November 18, 2003 ; accepted January 15, 2004)

\author{
The U.S. Middle East Policy and Japan \\ - the Implication of the Bush "Middle East" Doctrine on Japan-
}

\title{
Yasuyuki Matsunaga
}

\begin{abstract}
The September $11^{\text {th }}$ attack on the U.S. prompted the Bush Administration to base its Middle East policy on a set of assumptions very different from those on which the previous Administrations' policies were based. In its turn, the Bush "Middle East" Doctrine, which has replaced the 1980 Carter Doctrine, requires us to fundamentally reconsider how best to secure Japan's national interest in the Persian Gulf region.
\end{abstract}

Key words : U.S. Administration, Middle East Policy, Persian Gulf, Carter Doctrine, Bush Doctrine, democratization, Japan, national interest

\section{1.はじめに}

本日の主題は「米国の対中東政策と日本」ということ でありますが，基本的にお手元のレジュメにしたがっ て，なるべく明快かつ簡潔に結論に到着できるように話 を進めさせていただきます。

本日議論したいことは，ブッシュ政権が現在の米国の 政権であるわけですが，単にブッシュ政権が続く間だけ ではなくて，その前後をも捉えるパースペクティブにお いて，米国の対中東政策がマクロな観点から現在どのよ うになってきており，これからどのようになっていくの か。また，それが日本の国全体に対してどのようなイン プリケーションを持っているのか。特に後者の部分が, 今日私が最む括ししたいポイントであります。それを 考えるための背景，また前提となる分析から話しを進め

$*$ 平成15年10月 21 日, 平成 15 年度石油技術協会秋季講演会で講 演 This lecture was delivered at the 2003 JAPT Autumn Meeting held in Tokyo, Japan, October 21, 2003.

** 日本大学国際関係学部 Associate Professor Nihon University

Copyright (C) 2004, JAPT
ていきます。

\section{2. ブッシュ政権の対中東政策の位置付け}

ご承知のとおり，2001年 1 月にブッシュ政権が成立 し，現在まで 2 年半から 3 年弱が経過しております。 ブッシュ政権の対中東政策を語る際に，2001年 9 月11日 のいわゆる「9.11米国中枢同時テロ」事件を無視して語 ることはできないことは，明らかです。ところが，9.11 事件は, ブッシュ政権にとって非常に影響力のある，い わば分岐点となるような事件であっただけではなくて, これからお話する私の見方に基づけば，米国の歴代政権 が拠って立っていたものへのインパクトも非常に大きな あのがあった。それはいわば，今から24〜25年前になり ますが, 1979年のイラン・イスラム革命に次ぐ，大きな 事件であったとみなすべきむのである，と考えます。

振り返って考えますと,ブッシュ政権というのは2001 年 1 月の成立時に，何か決まった対中東政策というもの を持って米国内で権力の座に到達した，というわけでは ありませんでした。あちろんその前に民主党のクリント ン政権が8年間続いていましたから，それとの差異化と いうのが最大のポイントでありました。ジョージ・ 
$\mathrm{W} ・ フ ゙ ッ シ ュ$ 候補が選挙キャンペーン中にいっていた ことは，基本的には，「民主党の外交政策，安全保障政 策というのは失敗である。それを根本的に見直さなけれ ばいけない」ということに，つきていたわけです。

当然もう少しマクロ的に見ますと, クリントン政権の 前の 4 年間がブッシュ・シニアの政権であったわけです し, 現在の時点から振り返って考えますと, 現ブッシュ 政権に, ブッシュ・シニア政権の中に入っていた人たち が, かなり多数返り咲いていることも, 重要な特徴で す。チェイニ一副大統領, ウルフォウィッッ国防副長官 などがそうですし，コンドリーザ・ライス安全保障補佐 官などもブッシュ・シニア政権の NSCにおりましたか ら，人脈，パーソナルなレベルであ継続性があるわけで す。

したがってブッシュ人脈の人たちから見ると，クリン トン政権の 8 年間というのは，「間に挟まった無䭾な 8 年間, 失敗の連続の 8 年間」であって, それと差異化を することが重要であったことになります。したがって, クリントン政権の政策を「見直す」というのが, 政権に 到達した 2001 年 1 月時点での最も重要な立場, 姿勢で あったわけです。

ところが, ご承知のとおりブッシュ，ゴア間の得票 を数え直す問題で, 政権発足が若干遅れたこともあり, 政権の陣営あるいは政策的な枠組みを立ち上げるのが若 干遅れていました。したがって, ブッシュ政権が成立し て, クリントン政権の外交・安全保障政策を根本的に見 直すという作業をちょうど進めているところに，9.11事 件が起こったというわけです。この事件は, 申し上げる まであなく，米国本土に対する直接的な攻撃であり，さ らに相手が国ではなくてサブステート（準国家主体）の いわゆる「テロ集団」であったことが特徴でした。特 に, 本土に対する大規模攻撃という意味では, アメリカ 建国以来ほとんど初めて遭遇した, 非常に大きな事件で あったわけです。

したがって，この事件の米国の治安・安全保障政策全 般に対する影響ははかり知れないものがあったわけで す。本日は，対中東政策に限って見ていきますが，それ でも当然ながら，9.11事件のインパクトは非常に大き かったといえます。といっても，その前日まで進んでい た対中東政策の「見直し」が，9.11事件の後で全部白紙 に戻り，その後の新たな政策は全くゼロから出てきた， というわけでは当然ありません。やはり, 何らかの継続 性は当然あるわけです。

それでは，何が変わったかということを，考えてみた いと思います。一般に, 国家としての米国の対中東政 策, 対外政策, それから安全保障政策などは, どのよう
な枠で区切っても，それは 1 つ要素からだけ規定され ているわけではなく，それぞれに多数の要素がかかわっ て構築されております。そこで, それらのいろいろな要 素を結び合わせている「有機的な連環」を作り直させた あのが，9.11事件だったといえると思います。つまり， 要素的には前からの継続というのが当然あるわけです が，それぞれの位置付けとか，意味合いとかを規定して いる，大きな枠組みを根本的に変えてしまったものが, 9.11事件であった，ということです。

では，どういうふうに変わったのか，という話しをさ せていただきますが, 時間の関係で, 若干乱暴ですけれ ども話を，以下のように簡略化させていただきます。つ まり， 9.11 事件から 2 年ちょっ之経過しておりますが, ここでは, 結局どういうことになっているかということ から逆算した結果に基づき, 話をしたいと思います。現 在の視点から見直す之, 事件直後には見えなかったこ と，つまり，9.11事件が米国を外交政策的にどういう方 向に変えるものであったのかが， 2 年たっているために より良く分かるからです。そういう現在の視点から再構 築した話を，これからさせていただきます。

米国の対中東, 特に対湾岸政策に関して重要な宣言 に，1980年の「カーター・ドクトリン」があります。 カーター・ドクトリンは, 基本的にはその後のレーガン 政権, ブッシュ政権, それからクリントン政権と，かな り性格が違う政権が続いたにもかかわらず，一貫して維 持されてきておりました。中東・湾岸地域の個々の国に 対する政策は変わったりしております。しかし全体とし ては, 歴代の政権は, 基本的にカーター・ドクトリンの 枠組みの中で，個々の政策的対応をしてきました。

ところが，現ブッシュ政権は，9.11事件後にこれに代 わる新しい「ブッシュ・ドクトリン」なるものを定式化 してきている，というものが私の議論です。このブッ シュ・ドクトリンは, いわゆる「先制攻撃ドクトリン」 としていわれているあのとは違うあのであり，私自身の 命名ですが，いわば「対中東ブッシュ・ドクトリン」と いうものがある, ということです。さらに,この新しい 「対中東ブッシュ・ドクトリン」は, 1980年のカー ター・ドクトリンの前提を根本的に改編した，新たな前 提の上に立っているドクトリンである, というのが今日 の私の議論の第 1 の論点です。

それでは, カーター・ドクトリンというのはどういう あのであったのか, 簡単におさらいをいたします。カー ター・ドクトリンが宣言されたのは，1980年 1 月の一般 教書演説です。米国の大統領は，毎年1回，1月の末に 議会に出向いて，「ステート・オブ・ユニオン・アドレ ス」, つまり一般教書演説といわれている, 所信表明演 
説を行います。1980年のこの一般教書演説において， カーター大統領は次のように述べています。長い演説の 中での 1 つの箇所ですが，なるべく直訳しますと次のよ うになります。「域外勢力によるペルシャ湾地域のコン トロール獲得へのいかなる試みも，アメリカ合衆国の死 活的な利益への攻撃（assault）であると見なし，軍事 力を含む必要な手段で排撃する」，というものです。

これが，どういう文脈で語られたかと申しますと， 1980年 1 月ですから，1979年2月のイラン革命から11力 月後でした。それから1979年12月末にはソ連がアフガニ スタンに侵攻しました。この大きな 2 つのできごとが背 景にあるわけです。さらに，その間の1979年11月には, テヘランの米国大使館が占拠され，60人前後の大使館員 が人質になっています。その人質事件が続いている中 で，アフガニスタンにソ連が侵攻し，その 1 ヶ月後の演 説ということになります。少々付言すると，1980年 4 月 に人質救出作戦というのをカータ一大統領が実行するわ けですが，これがあのの見事に失敗しました。その人質 救出の前後に, 米国はイランと国交を断絶するわけで す。したがって，カーター・ドクトリンの宣言は，米国 とイランの国交断絶の前であって，大使館占拠事件の後 ということになります。

ところで, 人質救出事件失敗の時点では, 米国の方か らもう国交断絶していますから，これは要するに，その 時点ではアメリカは親米国家としてのイランというもの を完全に失ってしまった，という自覚をしていたことが 分かります。ところが， 79年 2 月当時のアメリカ政府の 認識というのを今加考えてみると, 若干面白いという か不思議な感じさえします。79年 2 月, つまりイラン・ イスラム革命が成立した当初というのは, アヤトラ・ホ メイニーもすでに鹵ってきているわけですが，米国はま だ大使館をそこに維持しております。まだ，「この新し い体制と我々はやっていけるのではないか」という感触 があったわけです。今から考えると、これは完全な読み 違えであるといえますが，当時はそういう感触があった ことになります。

ところが，11月に米国大使館を占拠するまでの間，イ ランは何をしていたかというと，今まさにイラクでなさ れようとしていること, つまり, 憲法の草案を作り, 憲 法制定会議を開き，新しい体制をどう作っていくかとい うことを，けんけんごうごうと議論していたわけです。 当時, テヘランの米国大使館はそれを見ているにもかか わらず，自分たちが最終的には追放されるということに まだ気が付いていなかった。むしろ逆に，親米勢力を伸 ばそうといろいろ画策していたがために，大使館占拠之 いう事件を招いてしまったという部分があるわけです。
さて，11月に大使館が占拠され, 続く12月の末にソ連 がアフガニスタンに侵攻します。その文脈において， カーター・ドクトリンとして知られるようになった, 「ペルシャ湾におけるコントロール獲得の試みという屯 のを，米国合衆国の死活的な利益への攻撃であると見な す」という一般教書演説の一文が，何を意味していたか を見てみると，まず気付く点は，米国が非常にディフェ ンシヴ（防衛的）になっていることです。つまり，イラ ンで革命が起こって米国の「影響圏」が後退しているな かで，ソ連がアフガニスタンにまでやってきている。当 時, ソ連はこの後ペルシャ湾まで南下して来るのではな いか，という危惧がありました。つまり，アフガニス夕 ン, パキスタン, ペルシャ湾と, 順次降りて来るのでは ないか, という危惧です。元々,「ソ連は不凍港を求め て南下してくることを狙っている」という疑念があった ため，米国としても，ペルシャ湾地域に対する「囲い込 み」が進んでいるという認識があったわけです。そのよ うななかで，ハト派で「ウインプ」(弱虫）だという評 判が国内的にああったカーター大統領が，非常にタカ派 的に強く出たのが，このカーター・ドクトリンの宣言 だったわけです。いい換えると，「これ以上の失地は許 さない。現状を何としてでも守り抜く」という宣言で あったわけです。

そのような枠組みのなかで，その後，米国はサウジア ラビアに AWACS（早期警戒管制機）という最新鋭の 軍用機を供与し, イラン・イラク戦争が始まると, サダ ム・フセイン大統領のイラク・バアス党政権に対する傾 斜を徐々に強めていくわけです。それからブッシュ・シ ニア政権期には，イラクのクウェート侵攻に対して湾岸 戦争という形で対処し，そのあとクリントン政権では, 「二重封じ込め」という形で政策を作っていきます。

これらすべてに一貫していることは何であったかと考 えると，要するに，「ペルシャ湾の現状をこれ以上変え たくない。現状をどうしても維持する」，という姿勢で す。いい換えると，「現状を変えるものは，すべて米国 の死活的な利益に対する攻撃であると見なす」，という スタンスだったわけです。

ところが，9.11事件の後に出てきた「対中東ブッ シュ・ドクトリン」は一そういうあのがあるとすれば一 どういう前提に立っているかというと，それは，「現状 が問題である，現状をこのまま放っておくことはできな い」というあのです。つまり，全く逆です。カーター・ ドクトリンが,「現状を守らなければいけない」といっ ていたのに対し，ブッシュ・ドクトリンは，「現状こそ が問題であるから，現状を変えないといけない」，と いっているのです。これが, 対中東ブッシュ・ドクトリ 
ンの第 1 番目のポイントです。

さらに, 第 2 番目の重要な点は, カーター・ドクトリ ンというのはあくまでも，「米国の外国における利害に 対する攻撃」, 自国が「中東湾岸地域に持っている利害, 権益」というものに対するプラス・マイナスの話をして いたわけです。ところが，この9.11事件後の「ブッ シュ・ドクトリン」は, 中東地域を今のような形で放っ ておくことは「米国の安全保障」にかかわる重大な問題 である，という前提をあつものです。つまり，自国の安 全保障というものと, 中東地域の現状が続くのか変わる のか，ということを直接リンクさせたものです。した がって, 対中東ブッシュ・ドクトリンは, この二重の意 味でカーター・ドクトリンを根本的に変えるものだった のです。

この変化の背景にあるのはあちろん，例えば 9.11 事件 の実行犯となったハイジャック犯19名のうちの18名が, 「穏健派」といわれているアラブの「親米」国の出身 だったことなどの事実です。19名の内訳は，15名がサウ ジアラビア， 2 名が UAE，エジプトが 1 名, 残る 1 名 がレバノンだったわけです。そこで，仮にレバノンを親 米国家ではないと数えると，19名中の18名が「親米のは ず」の国から出てていたわけです。ここには，1つに は，「政府が親米であっても，国民が親米であるとは限 らない」という，ある種自明な事実が，存在していたこ とを示しています。

しかしょり重要なことは, ブッシュ政権, それから米 国の「フォーリン・ポリシー・エスタブリッシュメン 卜」(外交政策エリート) のほとんどが，9.11事件を一 過性の問題であるとは捉えなかったことです。むしろ， 「前からいろいろな兆候が出ていたにもかかわらず，そ れを放っておいた『付け』が回ってきた，そのような放 任主義への『ウエイク・アップ・コール』であった」, と解釈したのです。つまり，これが一過性の問題であっ たのであれば，この $19 人 之$ 直接関係していた 20 人なり 30 人なり50人というものを捕獲して裁判にかければ済んだ わけです。ところがそうではなく，これはあくまでも 「水山の一角」であって, こういうことがさらに続くこ とを食い止めるためには，さらに米国本土の安全保障と いうあのを守るためには，この中東地域，つまり「この ようなテロリストの過激派が出てくるような土壌」を, 根本から変えなければいけない，という認識が，米国国 内，特に外交政策エスタブリッシュメント，民主党，共 和党を含めてすべてのスペクトラムでミニマム・コンセ ンサスとして，すでに確立している，というのが私の第 3 の論点であります。

いわいわゆる米国内の「強硬派」, あるいは「ネオ・
コンサバーティブ」（新保守派）という一派が，メディ アも含めて注目を浴びておりますけれだあ，「中東をこ のまま放っていくわけにはいかない」という考え方は, 単にネオコンだけが主張している話ではないのです。ま た，単にブッシュ政権のライス補佐官だけがいっている こと，ではないのです。これは，米国の外交政策エス夕 ブリッシュメントの間で広く見られる，ミニマムなコン センサスであるということです。卆ろん，あっと「過 激な」主張をする人もたくさんいるわけですが，「最低 限，このまま放っておくわけにはいかない」ということ ではコンセンサスがある，といえるということです。

あまり時間がないので，2つだけ例を挙げさせていた だきます。ファリード・ザカリアという外交政策エス夕 ブリッシュメントのプリンス的な人の話があります。彼 はもともとインド生まれの，インド系米国人で，イエ一 ル大とハーバード大を出て政治学の博士号を持ってお り，「フォーリン・アフェアーズ」という雑誌の編集長 を長くやっておりました。現在はニューズウイーク誌の インターナショナル・エディターをやっております。彼 は全くネオコンではなく，いわばネオコンとは正反対 の, 国際協調派, 良識派, リベラル派の人です。その彼 が，9.11事件の直後に二ューズウイーク（10月15日号） にかなり長いエッセイを書いています。そこで非常に直 接的ないい方をしているのですが，「9.11事件というの は, アラブの失敗した社会の生産物である。アラブ社会 というのは何重の意味であ失敗をしている」，それから， 「これを放っておくわけにはいかないから，変えなけれ ばいけない。何を 1 番変えなければいけないかという と，文化を変えなければいけない，イスラムという宗教 を秪健化させなければいけない」，といっています。彼 自身むムスリムだとは思いますが，非常にアメリカナイ ズされてきており，あともとアラブ人ではありませんか ら, そこでは外からの視点で, あちろん米国側の視点で 語っているわけです。それにしても，彼のようないわば 非常に良識的な人が，そこまで踏み込んで発言をしなけ ればいけないような状況があるという認識を持っている ことが分かります。さらに，これは彼だけがいっている ことではなくて，インディカティブ（示唆的）といいま すか，今の米国の外交政策エスタブリッシュメント全体 のようすを象徴しているすのだと思います。

それからあう1つだけ例を挙げさせていただききま す。イラク戦争後の 5 月か 6 月ぐらいの頃だったと思い ますが, 対イラク強硬派として知られるウルフォウィッ ッ国防副長官が，イギリスの「IISS」という戦略研究所 での講演後の質疑応答のなかで，「WMD（大量破壊兵 器）がイラク戦争の大義であったにもかかわらず，全く 
見つかっていないではないか。これをあなたはどう思っ ているのか」という質問に対し，彼は「いや，実は WMD というのは, 我々米国政府内のいろいろな省庁 間協議の中で唯一皆が合意できるミニマム・コンセンサ スだったから，(大義の）先頭に上げただけだ。あれだ けの理由で米国がイラクに対して戦争したわけではな い」,という発言をしています。

これは何をいっているかというと, やはり彼も, ザカ リアといっていることは同じなわけです。「中東地域, 特にアラブ世界というものを今のような形で放っておく ことはできない，つまり，根本的な変化というものをそ こで起こさせない限り，中長期的な米国の安全保障とい うのは確保できない。だから，イラクという国の中に WMD が何個あるかということは，非常に大きな絵の 中の小さい要素であって，核心的な部分ではない」，と いうことをぽろりといってしまったものであると，私は 位置付けております。

「対中東ブッシュ・ドクトリン」について, さらにも う 1 点だけ，その特徴を指摘させていただきます。従 来, 米国の歴代政権の対中東政策の柱というのは 2 つ あって,これは第二次世界大戦後大体ずっと一貫してい ます。特に，オイルショック以降の過去30年，35年の間 の米国の対中東政策というものは，以下の 2 本柱を明示 的にもつものでした。

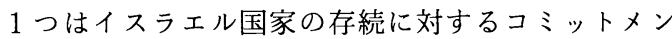
ト。つまり，「イスラエル国家を地中海にたたき落とし て, 地図から抹殺する」という主張の正反対の内容への コミットメントです。米国は国家として，イスラェル国 家が存続することに対して，（後者の）「建国」のその日 からコミットしている。これが 1 つの柱です。

あう 1 つは, 先程の「カーター・ドクトリン」が踏襲 しているものです。つまり, ペルシャ湾岸に重要な産油 国がある関係で，「ペルシャ湾岸地域の安定に米国は死

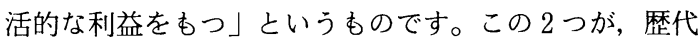
米国政権の対中東政策の両軸であったわけです。ときど きこの 2 本の軸が衝突をすることがあった。つまり，イ スラエルに対するコミットメントと，アラブ産油国に対 する友好関係維持という，2つの機軸が時に大きく衝突 することがあったわけです。それが例えば，1973年の中 東戦争などの時に露骨に表面化したわけです。それを今 まで，うまくやりくりしてきたのが，米国の中東政策で ありました。ところが 9.11 事件以降のブッシュ・ドクト リンは，それを一元化したわけです。あはや軸は 2 つで はありません。1つです。

これはどういうことかというと，ブッシュ政権は，対 中東政策のすべてを「対テロ戦争」という枠組みで包括
している，ということです。いわゆる「パレスチナ問題 あ」, 今までの米国歴代政権にとっては, 自らに直接か かわる問題ではなく，あくまであ「イスラエルが抱える パレスチナ人に関する問題」, ということだったわけで す。ところが,「パレスチナ問題＝イスラエルが直面す る『テロ』の問題」である，ということにしてしまう と, 軸が一元化できるわけです。また今までは, 先程申 しましたように,「中東湾岸地域の安定とか, その地域 内に存在するそれぞれの個別の権益というのは, 米国の 利害にかかわる」という話だったのですが, 中東地域で 起こっているすべてのことを，米国本土の安全保障とリ ンクさせるかたちで一元化したというのが，この「対中 東ブッシュ・ドクトリン」の基本的な特徴である, と私 は考えています。

それでは，仮に議論のためにそういうものだとする と, どういうことになるか, という話を次にさせていた だきます。

\section{3. 単なるレトリックなのか? それ以上のものがあるのか?}

「対中東ブッシュ・ドクトリン」には, その内容を分 析的に見てみると, 表と裹があることが分かります。別 のいい方をすると，それはいわば円周のようなあので あって, 努力して円周を半分進んでも, それはまだ最終 ポイントに届いたことにならない。あう半周してぐるり と戻ってきて，これでやっと成果が上がったといえる， という類のあのである，ということです。したがって， 半分行ったところで手を緩めてしまうと，それはまだ何 もやっていないことに等しい。ブッシュ・ドクトリンは そういう関係から成り立っているものだといえます。表 裏一体で，あるいは一周でワンセットのドクトリンであ る, という形になっている。ここで, 表面あるいは最初 の半周は，いわゆる「対テロ戦争」というあのです。で は裏面あるいは残りの半周は何かというと, それは, 中 東の「民主・リベラル化」です（図 1 参照)。

この後半部分は，いわゆる中東の「民主化構想」とい

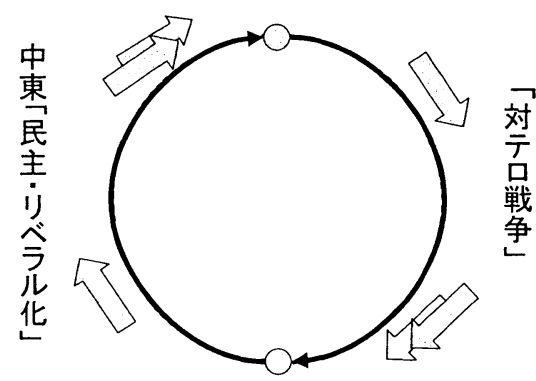

図 1 対中東「ブッシュ・ドクトリン」 
われているもので, ブッシュ政権の高官や大統領自身 が，これまでいくつかの演説で内容を明らかにしている あのです。ところがこの中東の「民主化構想」には，き ちんと理解されていない部分があります。しばしば，民 主化とは「選挙をやること」である，あるいは「議会選 挙をやって多数党が政権に就くことである」，という理 解がされがちです。その結果, 例えば, 「選挙をすれば イスラム政党や, イスラム過激派が政権に就く可能性が あるではないか。どうして米国はそういうことをやりた がっているのか。自分で自分の首を絞めることになりか ねない」というコメントあるいは批判をする人が少なく ありません。

しかし，ブッシュ政権，あるいは米国の外交政策エス タブリッシュメントがいっているところの「民主化」と は，単に選挙をやることではなく，「民主・リべラル 化」，つまり「リべラル化を伴う民主化」，ということで す。先ほどあ言及したとおり，米国の外交政策エスタブ リッシュメントが，現在のアラブ社会の問題をどのよう に見ているかというと，基本的には，「現在のアラブ社 会において，自然発生的な社会的行動が，『反米』とい う形で出てくることにある」，と見ているのです。これ は，単に米国への不満がたまっているという意味での 「反米」の問題ではなくて，むっとプロアクティブなレ ベルでの「反米」,つまり米国の利権あるいは米国本国 に対する具体的な「攻撃」という形で出てくるような社 会的・文化的特性，これに問題があるという認識です。 したがって，これを変えなければいけない，となるわけ です。

したがってこれは，ただ単に選挙という制度を導入す ればいいということではなくて,「自由選挙を行って, 親米勢力が勝つような社会」に作り変えなければいけな い，ということになります。さすがに言葉（アラビア 語）まで変えなければいけないといっていませんが, 「文化を变えなければいけない」,「宗教（イスラム）を 変えなければいけない」，「価值観を変えなければいけな い」,「プライオリティー（優先順位）を变えなければい けない」，といっているわけです。そのように「文化」 を問題にしている，ということはただごとではありませ ん。通常,「文化」という言葉でわれわれは，そう簡単 には変わらないもののことを指すわけですが，それを変 えようとしているわけです。

しかも，どこか一国の話ではないのです。イラクや 何々というそれだけの国の話ではなく，中東地域全般, 特にアラブ地域というあのが問題である，との認識が背 景にあるわけです。19人のハイジャック犯全員アラブ人 だったわけですから，ある意味では，非常に直接的な，
分かりやすい「論理」であるとあいえますが，「アラブ 社会のもつ問題を解決しなければアメリカ本土は安全に なれない」ということです。したがって，「対テロ戦 争」というのが終わったときには，その次の第 2 フェー ズであるところの「社会のリベラル化」というのをやら ない限りは，第 1 フェーズをやった価值がなく，米国国 家としての安全保障は確保できたことにならない，とい うことです。

現在米国が「対テロ戦争」というときの「ウオー・オ ン・テロリズム」は，実際の行動を見ていただければ分 かりますように，そこで「テロリスト」と呼ばれている のは，いわゆる「イスラム過激派」ばかりです。さら に，東南アジアのインドネシアとかフィリピンで，ある いはタイとかマレーシア辺りで行われているあのを除く と，すべて中東地域にその「前線」があるわけです。そ れ以外のコーカサスや中国などの「イスラム過激派」 は，それぞれロシアの問題であり，中国の問題であると いうことで，米国は前線では関わっておりません。した がって米国のいう，「ウオー・オン・テロリズム」のテ ロリズムは，小文字の「t」で書かれていますが，本当 の意味合いは，固有名詞としての大文字の「T」です。

ぞういうことかといいますと，米国にとっては「「イ スラム過激派」が問題なわけです。つまり，「中東の問 題」は「テロリズムの問題」であるとの基本認識がある わけですから，中東で，「イスラム過激派が出てこない ような土碾」を造り上げない限りは，問題は終わらな い。ここで議論のために，仮にこれが実現可能なことて あるとしても，想像を絶する大事業なわけです。した がって，そのようなものを「米国は本当にやる気なの か」という問題がでてきますが，それについては，私は 本気であると思っております。あし私の議論しているよ うに，ブッシュ政権の高官だけが考えていることではな くて，米国の外交政策エスタブリッシュメントが広くそ う考えている，ということであれば，政権が変わって あ，そういう基本的な，あるいはミニマムな合意部分は 一個々の発言の仕方や実際の行動や，またプログラムの ドラスティックさ（徹底的な度合い）というのは若干ス ローダウンする可能性があるとしても一基本的な方針と して続いていく可能性がある。つまり，「カーター・ド クトリン」以来の「ブッシュ・ドクトリン」というのが 新たに構築されたとすると，これは明日，あるいは来 年，終わりがくるようなものではなくて，しばらく，例 えば20年ぐらいは，続いていくかもしれないようなもの である，ということです。われわれは，そういう変革の 時期に今いるということであろうと思います。 


\section{4.「イラク戦後」の展望}

続いて，イラク戦後のブッシュ政権のプライオリ ティーはどうなっているかを，このブッシュ・ドクトリ ンとの関係で検証したいと思います。

大規模な戦闘が 5 月 1 日に終了したと宣言され，その 後ブッシュ大統領とブッシュ政権の高官らは何をしてい たか。つまり，イラクの現在の問題が表面化してくる 前, 米兵に対する攻撃とかサボタージュというのが明ら かな形で出てくる前, つまり, 戦勝ムードに乗っていた ころのブッシュ政権というのは何をしていたかを思い出 してみると, ブッシュ大統領は 5 月 9 日に, サウス・ キャロライナ州コロンビアでサウス・キャロライナ大学 の卒業式に出席し，そこで中東の「民主化・自由貿易圈 構想」というのを打ち上げております。

それから，ヨルダンのアカバで中東和平のサミットを 開きました。シャロン首相とアブー・マーゼンという当 時のパレスチナ自治政府の首相を呼んで, アカバで会合 を開いたのが 6 月 4 日です。つまり，5月，6 月という 時は, ブッシュ政権の対中東政策は以下のようなプライ オリティーになっていたと思います。

まず 1 番はイラク統治です。 2 番目がロードマップ, 3 番目が先程の中東民主化・自由貿易圈構想。それから 4 番目としてイラン問題, 5 番目はシリア問題, 6 番目, アルニカーイダ・アフガニスタン・ターリバーン問題。 大体こういう優先順位だったと思います。ところが, 現 在それからかなり状況が変わってきており，ご承知のと おりイラクは引き続き問題が山積しており，これがうま くいく方向に進むのか，そうでないのか明確にならな い。占領軍に対する攻撃の問題とか, 本日の何人かの講 演者の方が指摘しているように，国防省と国務省の間の あつれきの問題があったり, 国際的な支援や援助を確保 するのに非常に苦労しています。

それから，ロードマップについては，アブー・マーゼ ン首相は早くも辞任してしまいました。さらに先週，ガ ザで米国の外交官車両に対する爆弾（地雷）攻撃という のがありましたが, これは非常にソフィスティケートさ れた軍事オペレーションでした。そういうことに直面し ている。したがって, 最初の 1 番, 2 番というのはうま くいっていない。3 番目の中東民主化・自由貿易圈構想 などは，どこに吹っ飛んだのか分からないような状態に なっているわけです。

こういう状況を見たときに，われわれは，米国の対中 東政策というのはどうしてこれほど一貫性のない, 行き 当たりばったりであるのか, とあ解釈可能です。しかし 果たしてそういう見方が正しいのかどうか。私は先程の
「対テロ戦争」，それから中東「民主化・リベラル化」と いうのが基本的な大きな路線であるとすると，ブッシュ 政権の対中東政策のハンドリングは，必ずしも一貫性が ない行き当たりばったりの，失敗の連続ばかりのもの之 は見えないし，そう見るべきではないと思います。なぜ ならば，ブッシュ政権の対中東「ブッシュ・ドクトリ ン」が意味していることは, 次のようなことだからで す。

それが意味していることは，「中東地域を短・中期的 に混乱させることになっても，米国の安全保障にとって 必要なことであるから，やり遂げなければいけない」, ということです。ロードマップというのは, 一部で論評 されるように，「アラブの民衆の反米感情を静めるた め」,「アラブの民衆に対してこびるため」に持ち出した あのではないのです。つまり, 現在「ロードマップ」と 称されているものは, クリントン時代あるいはその前の 「和平プロセス」(ピース・プロセス）之呼ばれていたも のとは, 根本的に意味付けが違うわけです。例えばロー ドマップでは, PA（パレスチナ自治政府）の「レジー ム・チェンジ」をやらなくてはいけない,「アラファト はずし」が必要であるなどいわれていますが，これは基 本的には「中東地域の民主・リベラル化のためには，ヤ セル・アラファトが率いている PA は変えなければなら ない」という理屈であります。したがって，アブー・ マーゼンが辞めたから, 放っておいているというのは, ブッシュ政権の描いている「大きな絵」の中では，極め てロジカルなことなのです。

それから，イラクの中で米兵に対する攻撃というのが 続いていますが，これは「短・中期的な混乱」あるいは 「短・中期的なコスト」であって，こういうことを経る ことによって最終的にイラクの文化なりイラクの社会と いうあのを変えなければいけない, という計画があると 考えると，このような「短・中期的なコスト」というあ のは織り込み済みである，ということになります。こう いう流れの中での唯一の問題は, 来年ブッシュ政権が再 選されないとすると，その継続性に関して若干ギクシャ クする問題が発生する可能性はあるわけですが，再選さ れた場合には， 4,5 年のタームでやっていけることに なります。そうであれば，ひょっとしたらブッシュ政権 の描く方向でだんだん，土台作りが進む可能性もないわ けではない，といえると思います。

しかしここで申し上げたかったことは，これは先程の 「対中東ブッシュ・ドクトリン」の表と裏, 前半周と後 半周という枠で考えると, 必ずしも失敗の連続というふ うに見るべきではない，ということです。時間の関係も ありますので, イランの問題について話をする予定だっ 
たのですが割愛させていただきます。

\section{5. 日本へのインプリケーション}

本日の第 2 の論点であります日本の対応についての議 論に入ります。まず前置きとして, 私は個人的には全く 反米ではないこと，また反「日本政府」であないことを 申しあげておきます。したがって以下の議論は，あくま であ「建設的な批判」との趣旨のものであることをご確 認ください。

日本国内で，米国のイラク戦争をめぐって，賛否両論 いろいろな議論がされました。日本政府は，最終的に， 「戦争」を支持をしたわけですし，これからあ復興支援 に協力していくという姿勢です。私は別にそれに根本的 に異存があるというわけではありません。しかし，それ らの「支持」や「協力」の理由付けには大いに不満であ ります。その点から話していきたいと思います。

日本の「イラク戦争支持」の立場を正当化する議論で は，基本的には，日米同盟関係，さらに北朝鮮問題が論 拠とされました。これは,「日本と米国の同盟関係とい うあのを強めなければいけない。したがって, 米国とイ ラクが戦争するのであれば，日本はイラクではなく，米 国を支持するし，米国がイラクで戦後復興を主導するの であれば，われわれは米国に協力をする」ということで すが, これは 1 つのロジックとしては当然, 理屈が通っ ていないわけではありません。

しかしながら，私が不満，あるいは物足りないと思う 理由は, これらがイラクにかかわる問題であるにもかか わらず，我々の行動について，中東に即した（正当化の ための）理由付けがなされていない，という部分であり ます。つまり，日本が中東で持つ個別利害というものへ の言及・考慮が明示的にされない形で，「米国がイラク に対して行う戦争，あるいはイラクで行う復興というも のに日本は支持・協力しなければいけない」，としかい われていない部分であります。それでは，なぜ中東地域 での日本の利害という要素を明示的に議論に組み込むこ とがなぜ必要であるか，例示的に述べたいと思います。

日本政府は，先週（10月15日），イラク復興へ当面 15 億ドルを無償供与すると発表しました。その際の官房長 官談話を引用すると，その理由は，イラクの民主的国家 としての再建は, 「中東地域の…平和と安定に極めて重 要であり, 石油資源の 9 割近くを中東地域に依存するわ が国の国益に直結」するあのである，となっておりま す。これがいっていることは，「エネルギー安全保障上， 中東湾岸諸国の安定は日本の国益に直結するものであ る。したがってイラクの安定はわが国の国益に直結する 一部であるから，イラクの復興に対して 15 億ドル拠出す
る」ということです。ところが，米国が「カーター・ ドクトリン」のままでイラク占領・復興を行っているの であれば，これは全く問題ないわけです。なぜなら， 「カーター・ドクトリン」自体が，基本的にこの談話の 理屈と同じあのに基づいていたからです。つまり，「中 東湾岸諸国の安定は，わが国（米国）の利害に直結して いる。したがって，現状を断固守ることが国益である」， といっていたわけです。

ところが，米国の対中東湾岸政策の根底にある前提自 体が変わっている，という私の議論が正しければ，米国 は，「短・中期的なコストあるいは短・中期的な不安定 が起ころうとも, 中東地域を根本的に変える。中東地域 を根本的にリべラル化する。文化を全部変えて，親米の 文化というあのができるまで戦い続ける，変え続ける。 プロアクティブでやっていきます」，という姿勢なわけ です。そういうことであるときに，「中東湾岸の安定が 日本の国益であるから，日本は米国に協力します」とい う理屈では，少なくない問題が生じるといわざるを得ま せん。

言葉に出すと非常に平板になりますが，ポイントは， 現下の状況では, 中東湾岸地域における日本の国益とア メリカの国益は, 完全に重なってはいない，ということ です。さらに，現在重なってないばかりか，今後ますま す食い違う可能性がある。短・中期的な夕イムスパンで いうと，むしろ衝突のほうが増えるのではないか，と考 えられます。そういうときに，日本が今までのような日 米関係重視の議論で，あるいは今までのような「中東の 安定=日本の国益」という感覚・認識で対応し，どうい う枠組みの中でわれわれはそれを追求できるのか，ある いは維持できるのかということを，きちんと議論しない と, 日本が中東地域に持っている利害と国益を維持しそ こなう，と考えるわけです。

あう少し具体的にいうと，1つの大きな問題は，これ が単なる「短・中期的な不安定化」で斉むのかどうかと いうことです。米国が成功するのであれば，最終的には 中東地域は安定をするでしょうし，またそこが「親米的 な文化」をあつ所になっていて屯，われわれが行くにあ たって別に問題が生じるわけではないでしょう。した がって, 長期的に米国のプロジェクトが成功するのであ れば，われわれにとってあ実害はない，したがって，支 援することはよいことだ，といえることになります。し かし，キー・クエスチョンは，「果たして成功するのか」 です。本日はあえてそれに対する私自身の回答は申し上 げませんが，プロジェクトが意欲的であるがゆえに，そ の分だけ余計に困難であることだけは明らかです。

本当はノーといいたいところなのですが，仮にノーと 
はいわないにしてあ，それであ注意しなければいけない ことが 2 つあると思います。1つは, 米国はあくまであ 「米国の安全保障のために中東地域に介入する」といっ ていること。2っ目として，アラブ側は，現状ですら嫌 米, 反米の「民意」が非常に強いことです。テクノク ラートのアラブ人たちはそうでもないのかむしれません が, 現在の状況は, 単に一般庶民だけが反米であるので はなくて，ミドルクラスやエリートの間でも反米の姿勢 を示す人々が増えており，さらに政権側もブッシュ政権 の言動には困り果てているという状況が存在していま す。

「ブッシュ・ドクトリン」の継続は, 各国の政治的傾 向の違いにもかかわらず, アラブ諸国, 中東諸国に対す る非常に強い「圧力」になります。つまり，いわゆる 「親米国家」からあテロリストが出てきたために，圧力 がかかる。いわゆる「反米国家」は「反米」と見られて いるわけですから, 当然イランのように圧力がかかるわ けです。結果として, 今までの米国との関係あるいは政 治的な傾向にかかわらず, 地域全部がその圧力の対象に なっている。これは何を意味するかというと，地域の側 からの反発は今後強まる方向にあるということです。つ まり, 一方で, 米国は地域諸国の意向に基づいてではな く, 米国の自身ために中東地域全体へ圧力を強めてい る。あう一方の中東諸国側の方は, 仮に最終的に「リべ ラル化」されることが可能であるとしても，見在および 近い将来において簡単にそういう変化を進んで受け入れ る状態には，全くありません。

では，むしこういう状況が起こっているときに，日本 はよ゙うすべきでしょうか。3つに絞って，私の提言をさ せていただきたいと思います。われわれは，基本的に次 の 3 つのことを念頭に置いて行動を選択することが良い のではないかと思います。1つ目は, こういう状況であ るので, 米国にあまり振り回されないようにする。ある いは, 振り回され過ぎないようする。つまり, 日本がイ ラク復興に貢献するの屯,「米国之の関係のため」とか 「世界の平和のため」とかそういうことは置いて, 日本 のために本当になるのであればやるべきですし，そうで ないのであれば，あう少し真剣にぎりぎりのところを考 えたほうがいいのではないか。つまり, 米国の国益と日 本の国益之が完全に重ならないという前提で, あう一 度, 米国の行動への協力に関する議論をゼロから作り直 す必要があるのではないか。

2 つ目は，第一のものと重なっている部分もあります が, 戦略的な思考之戦略的な行動というのがわれわれに とって必要である, ということです。当然企業の方は, 各社でとに戦略的な行動をされているわけですから, 釈
迦に念仏だと思いますが，国家あるいは日本国全体，ま たいろいろなセクターごとの方針や行動の決定におい て, さらに日本国内での議論においての, 戦略的思考と 加戦略的行動を導入することの必要性の問題でありま す。つまり，こういう現下の状況で中東へ出て行くとい うときには，日本にとってどのような戦略的な利害があ るかということを再確認して, 決断する必要があるので はないか。

3つ目。私はこれは幸いだと思うのですが，本日の複 数のスピーカーの方々がいわれていたことと重なる部分 があると思います。米国に振り回され過ぎないとするな らば，具体的にどうすべきであるかと申しますと，私 は, 地域のセンシティヴィティ（sensitivity）を重視 する方向を選択すべきだと思います。

つまり，根井さんの話にありましたように，今までの 日本の企業の発電所の建設とか病院の建設などで, 日本 人がイラクで非常に歓迎され感謝されているとか, 先程 のスピーカーの方も申されておりますとおり, サウジの 現場監督からも非常に評価され感謝されている。当然こ ういった評価を受ける行動を取れるということは，われ われにとってプラスな特質であります。米国国民全部で はありませんが大多数の人たちは, イスラムは異質なも ので, 問題だと内心は思っている。われわれ日本人はイ スラム対してそういう特別な強い感情というあのはむっ ていない。これは明らかにわれわれが持つアドバテージ なわけです。

さらにわれわれが，地域のセンシティヴィティという あのに今以上に配慮すると, 米国よりあ断然比較優位に なります。これを活用すべきである。つまり, 中東地域 で若年人口が増加しているという指摘を何人かの方がさ れたように, 結局残るのは人なわけです。中東に住んで いる中東の人たち, アラブ人, イラン人という人たち と，われわれとの人間としての関係なわけですから，彼 らのセンシティヴィティに対して理解でき, 協調できる われわれのセンシティヴィティというものを全面に出 す。

したがって, 日本が中東諸国との長期的な関係を維持 するためには，あるいは利益を拡大するためには，この 地域のセンシティヴィティを重視するという立場を鮮明 に, 明示的に出すことが, よいと思います。ご承知のと おり，米国は今，それと正反対のことをやろうとしてい るわけです。「センシティヴィティを欠く行動をとって, 摩擦や反発を招くという結果は, 短期的なコストに過ぎ ない。したがって, 最終的に地域が『民主・リベラル 化』あるいは『アメリカ化』すれば, 米国との間の感情 的なわだかまりとか，いろいろな文化摩擦的な問題はな 
くなる」という立場です。したがって，地域の人々への センシティヴィティを示すことをあえて控えて，そのよ うな配慮を必要とする「根本」を壊して解体しようと, しているわけです。私は，われわれは，それと逆のこと
をすべきだと思うわけです。

時間になりましたので以上でしめさせていただきま す。どうあありがとうございました。 